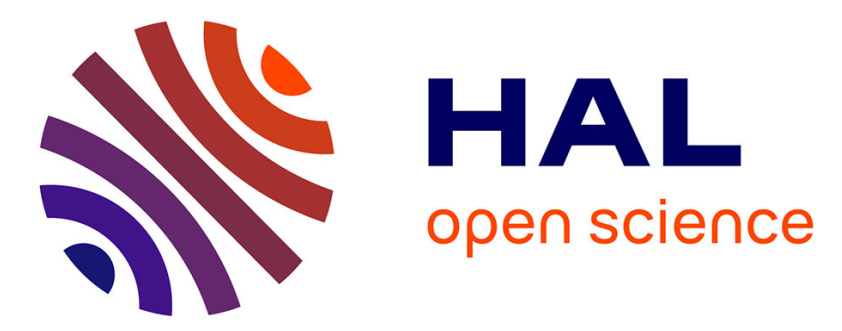

\title{
Null objects in second language acquisition: grammatical vs. performance models \\ Eve C. Zyzik
}

\section{To cite this version:}

Eve C. Zyzik. Null objects in second language acquisition: grammatical vs. performance models. Second Language Research, 2008, 24 (1), pp.65-110. 10.1177/0267658307082982 . hal-00570739

\section{HAL Id: hal-00570739 \\ https://hal.science/hal-00570739}

Submitted on 1 Mar 2011

HAL is a multi-disciplinary open access archive for the deposit and dissemination of scientific research documents, whether they are published or not. The documents may come from teaching and research institutions in France or abroad, or from public or private research centers.
L'archive ouverte pluridisciplinaire HAL, est destinée au dépôt et à la diffusion de documents scientifiques de niveau recherche, publiés ou non, émanant des établissements d'enseignement et de recherche français ou étrangers, des laboratoires publics ou privés. 


\title{
Null objects in second language acquisition: grammatical vs. performance models
}

\author{
Eve C. Zyzik Michigan State University
}

Received December 2005; revised July 2006; accepted January 2007

\begin{abstract}
Null direct objects provide a favourable testing ground for grammatical and performance models of argument omission. This article examines both types of models in order to determine which gives a more plausible account of the second language data. The data were collected from second language (L2) learners of Spanish by means of four oral production tasks and a grammaticality judgement task. The results reveal that null objects in oral production are rare events limited to pragmatically appropriate contexts, that is, when the referent is easily recoverable from preceding discourse. The results of the grammaticality judgement task indicate that beginning level learners frequently accept sentences containing null objects with specific antecedents, while more proficient learners categorically reject such argument omissions. It is suggested that lower proficiency learners may rely primarily on semantic strategies in parsing and evaluating sentences, while advanced learners are more sensitive to syntactic violations. A performance account is ultimately adopted to explain the data given the lack of a clear null object stage in development, the presence of self-corrections, and the discourse-constrained nature of object omissions.
\end{abstract}

Keywords: argument omission, null objects, direct object drop, Spanish clitics, anaphora, grammaticality judgement tasks

\section{Introduction}

Argument omission has been an important area of inquiry for both first and second language researchers because it motivates a series of theoretical 
claims about the possible interaction between language typology, Universal Grammar (UG), and the language acquisition process. It is clearly evident that there are cross-linguistic differences in the expression of arguments. For example, while some languages (e.g. English, French) require that subjects be phonetically realized, others do not (e.g. Spanish, Portuguese). Additional cross-linguistic differences arise in object position; some languages permit the object slot to remain empty whereas others require a lexical NP or pronominal object. The property is often referred to as object drop or a null object, although other terminology is equally suitable to describe it. ${ }^{1}$ Without a doubt, the situation is much more complex than presented in this brief introduction, given that each language is sensitive to a number of syntactic, semantic, and discourse factors that license the presence of null elements.

For language acquisition researchers, the locus of inquiry centres on the documented cases of argument omission that deviate from the target language (i.e. the adult native speaker norm). For example, although English is not a null subject language, young English-speaking children often produce utterances with missing subjects (see, amongst others, Hyams, 1983; 1986; Bloom, 1990; Valian, 1990; 1991). For those working with the nativist paradigm, this empirical finding prompted discussion regarding the initial setting of the pro-drop parameter and how children eventually converge on the adult grammar. Second language acquisition (SLA) studies have also documented the presence of illicit null arguments (see, amongst others, Gundel et al., 1984; Williams, 1989), which raises questions about the role of transfer and the kinds of hypotheses that guide second language (L2) learners in the acquisition process.

The present study explores null (direct) objects in Spanish, a phenomenon which has gone largely unnoticed by SLA researchers. With the exception of Bruhn de Garavito and Guijarro-Fuentes (2002), who targeted null objects via a grammaticality judgement task, there have been no empirical studies that set out to investigate null objects in the L2 context

\footnotetext{
${ }^{1}$ There are often subtle distinctions in terminology among null objects, pronoun omission, object drop and zero anaphora (see Williams, 1989). 'Object drop' is commonly used in formal linguistic approaches to syntax; it implies that an empty category occupies the argument position of the verb. In the context of L1/L2 acquisition, 'omission' implies that an error has been made, while the term 'zero anaphora' is more neutral and can refer to a legitimate discourse option. I employ the term 'null object' throughout the article to refer to the property of Spanish in which direct objects are not phonetically realized under certain conditions.
} 
and, moreover, no studies that examine the phenomenon in oral production. The present study intends to fill this gap in the research by documenting null objects in a spoken corpus from learners of various proficiency levels. The oral production data is further supplemented by results from a written grammaticality judgement task. The data set is considered in light of two possible explanations for the presence of null objects in L2 grammars. The first is a grammatical account similar to the one proposed by Fujino and Sano $(2000 ; 2002)$ for object omissions in L1 Spanish. Grammatical accounts (compare Hyams, 1994) propose that at a given stage in development, learners' underlying grammar licenses null arguments. The opposing view is a performance account in which the omission of arguments is seen as a result of processing limitations, as proposed originally by Bloom (1990) and Valian (1990). These conflicting perspectives reflect in many ways the competence-performance distinction that is often invoked in second language acquisition research (Gillian et al., 1996).

In L2 Spanish, the presence of null objects is particularly interesting since standard Spanish is classified by some as a non-null object language (Fujino and Sano, 2002). Although dialectal variation must be taken into account (see the next section), null objects with definite reference constitute a syntactic violation for most speakers of Spanish. Thus, the example in (1), uttered by an English-speaking learner, presents an intriguing problem because it cannot be explained by transfer or by positive evidence from the L2 input.

1) Y Pablo quita su abrigo y ... y $\varnothing$ tira encima del sillón.

'Pablo takes off her coat and ... and throws $\varnothing$ on top of the chair.'

This article has three objectives:

- to document the frequency and distribution of null objects in the oral production of L2 learners;

- to examine the relationship between null objects in oral production with the acceptance of null objects in a grammaticality judgement task; and

- to determine which theoretical explanation, the grammatical or performance account, is a better fit with the empirical data.

I begin with a brief overview of the main properties of null objects in Spanish, followed by a review of the literature on null objects in L2 studies. Next, I examine the arguments that have been presented in favour of 
both grammatical and performance accounts of null arguments. Before describing the methodology, I present a brief summary of the literature that has examined the relationship between grammaticality judgement tasks and oral production. The methodology section describes the tasks that were used to examine learners' oral production and intuitional judgements of null objects. After presenting the results, I return to each of the three objectives mentioned above.

\section{Null objects in monolingual and contact varieties of Spanish}

Null objects have attracted the attention of many linguists interested specifically in Spanish and/or Romance languages in general. As Schwenter (2006) points out in his thorough overview of the phenomenon, there have been two primary motivations behind their research:

- documenting the role of language contact and its contribution to the occurrence of null objects; and

- postulating the correct syntactic characterization of the null object within a formalist syntactic framework.

In contrast, the goal of this section is to provide a brief overview of the data from both monolingual and contact varieties of Spanish in order to appreciate the relative frequency of null objects in the input and the environments in which they tend to occur. These two aspects of the primary linguistic data - the frequency and distribution of any feature - will affect the kinds of hypotheses that learners entertain about the target language.

Typologically, standard Spanish is considered to be a non-null object language (Fujino and Sano, 2002), which means that objects with definite reference must be overtly realized, either lexically or with an object clitic. The relevant contrasts are illustrated in (2).

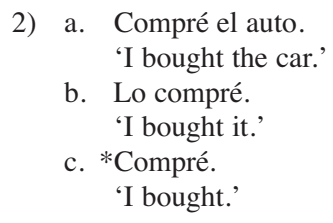

However, all dialects of Spanish allow for the object position to remain empty with generic referents that are non-specific (Campos, 1986; 
Clements, 1994; 2006). Example (3) and (4) illustrate this phenomenon with mass nouns.

3) Fui a la tienda a comprar pan integral pero no $\varnothing$ tenían. 'I went to the store to buy whole wheat bread but they didn't have (any).'

4) ¿Quieres café? No, gracias. Ya $\varnothing$ tomé. 'Do you want coffee? No, thanks. I've already had (some).'

Clements $(1994 ; 2006)$ considers such examples and compares them to the use of overt partitive pronouns in other Romance languages (e.g. ne in Italian, en in French). Both types of noun phrases - mass nouns and bare plurals - are non-referential since they do not refer to any particular item, but rather to a type (compare Givón, 1984). In this way, Clements demonstrates that null objects in Spanish are constrained by the specificity feature; specific referents must be overtly realized whereas arguments that are non-referential and non-countable can be null (i.e. null direct object pronominalization).

In addition to the null objects in examples (3) and (4), which are found in all varieties of Spanish, many dialects also allow definite direct objects to be null. Studies of contact varieties on the peninsula (for examples from Basque Spanish, see Landa, 1995) and in South America (Paraguay, Ecuador, Argentina and Peru) illustrate that null objects with specific referents are often the norm rather than the exception. Choi (2000) found extremely high rates of null objects among both monolingual Spanish and bilingual Guaraní/Spanish speakers in Paraguay. For example, the five monolingual speakers in her sample used null objects $90 \%$ of the time for inanimate referents; the rate of null objects among bilingual speakers was even higher, ranging from 90-98\%. Colantoni (2002) reports much lower rates of null objects in the province of Corrientes (Argentina), but the degree of bilingualism of her informants is not known. Importantly, Colantoni notes that null objects are exclusive to inanimate referents, are easily identifiable from preceding discourse and occur with a limited repertoire of transitive verbs such as hacer (to make), usar (to use), llevar (to carry), traer (to bring) and sacar (to remove), pedir (to ask for) and ver (to see). Colantoni's data confirm the earlier findings of Suñer and Yépez (1988), who documented a similar distribution of null objects in Quiteño Spanish: the referents of null objects are automatically interpreted as inanimate, null direct objects are favoured when an indirect object is 
already present, and the referent of the null object must be recoverable from the discourse context. In Peruvian varieties, null definite objects have also been documented among Quechua-Spanish bilinguals living in Lima (Escobar, 1990), but the occurrence of this phenomenon is most prevalent in highland areas and among speakers who are more proficient in Quechua than Spanish (Klee, 1989; Lipski, 1994; Paredes, 1996). Some researchers have proposed that null objects in Andean Spanish are due to transfer of null pronouns from Quechua among bilingual speakers (Camacho et al., 1997).

In the US context, specifically in the case of Los Angeles Spanish, Silva-Corvalán (1994) documented cases of direct object omission among Spanish-English bilinguals. This is primarily a trait of those speakers most dominant in English but, nevertheless, the rate of omission of direct object (DO) clitics (3.4\%) is much lower than that of other clitics (e.g. reflexive, reciprocal). Interestingly, the one example of direct object drop cited in Silva-Corvalán (1994: 124), given in (5), is identical to the kinds of omissions produced by L2 learners in the current study (see comparable examples in the results section).

\section{5) ... tenemos una [moto] y nosotros $\varnothing$ llevamos.}

'We have one [a motorcycle] and we take (it).'

This discussion leads back to the issue of standard Spanish as traditionally represented by monolingual speakers of non-contact varieties. Masullo (2003) proposes that null objects are possible in all dialects when the referent is salient in the immediate discourse situation. Consider the example in (6) from Argentine (Rioplatense) Spanish, as quoted in Montrul (2004: 190).

6) ¿Le retiro $\varnothing$, señor? (spoken by a waiter to a customer in a café) 'Shall I take (it) away from you?'

Schwenter (2006) provides further examples of the 'immediate context' restriction with commonly occurring imperative forms, such as in (7).

7) Apaga $\varnothing$. (said by one person to another upon leaving the room) 'Turn (it) off.' (i.e. the light, the television)

Recently, Reig and Schwenter (2006) examined corpus data from Madrid and Mexico City for null objects with propositional referents (i.e. those 
pronominalized by the neuter lo with verbs like decir 'to say', entender 'to understand'). Their findings suggest some differences between the two dialects with respect to lexical and constructional restrictions, despite similar overall frequencies of null propositional objects (50\% in Mexico City and $42 \%$ in Madrid).

To summarize, null objects in Spanish may not be as anomalous as previously assumed (Schwenter, 2006) and are not restricted to contact varieties, although this is clearly where they are most frequent. Thus, despite the traditional classification of Spanish as a non-null object language, null objects are present in the Spanish grammatical system and are manifested in several different ways:

1) the null objects that appear in all dialects with non-specific antecedents such as mass nouns and bare plurals (Clements, 2006);

2) the null objects that occur with specific referents that are easily recoverable from the immediate discourse context (Masullo, 2003); and

3 ) the null objects with propositional referents (Reig and Schwenter, 2006).

Montrul (2004: 205) advocates for more research in this area and speculates that 'Spanish may turn out to be a type of null object language, different from English and perhaps different from topic-drop Asian languages.' Given the variable nature of null objects in Spanish, a crucial problem for SLA researchers is to determine whether or not learners are exposed to input containing the structures discussed in this section. Although null objects with mass nouns and bare plurals are permitted in all dialects, Bruhn de Garavito and Guijarro-Fuentes (2002) suggest that this construction is extremely rare in the input. ${ }^{2}$ Furthermore, if we assume that classroom learners of Spanish have little, if any, exposure to contact varieties of Spanish, the input they hear is unlikely to contain many instances of null objects with definite reference. An additional consideration is the fact that the explicit teaching of direct object pronouns (both form and placement) occupies a central place in most first- and second-year curricula. Given the extensive practice that learners typically receive with these clitic forms, it would be most unusual for null objects to be presented as a viable way of making anaphoric reference.

\footnotetext{
${ }^{2}$ It is unclear if Bruhn de Garavito and Guijarro-Fuentes (2002) are referring to classroom input or input in general. To my knowledge, there are no data from corpus studies regarding the relative frequency of this construction type.
} 
A plausible assumption, in the absence of frequency data to the contrary, is that classroom learners of Spanish have limited exposure to null objects.

\section{Previous research on null objects in SLA}

Most SLA research on argument omission has focused on subjects and the various constructions related to the pro-drop parameter (Phinney, 1987; Liceras, 1989; Al-Kasey and Pérez-Leroux, 1998; Pérez-Leroux and Glass, 1999). A few studies examine the acquisition of zero pronouns in both subject and object position (for a study of Chinese as a second language, see Polio, 1995). These studies are fundamentally different from the present one because they examine the acquisition of a target language feature, not the illicit omission of arguments.

There are a few cross-linguistic descriptions of such object omissions among L2 learners. For example, studies on L2 French by Adiv (1984), Gundel et al. (1984) and White (1996) note that L1 English speakers omit objects; Véronique (1989) confirmed the same pattern for L1 Arabic speakers. In the ESL context, Gundel and Tarone (1992) document the use of null objects by native Spanish speakers. Zobl (1994) and Yuan (1997) report that Chinese learners of English accept null objects at relatively high rates in written tasks of acceptability (in contrast to more accurate performance with null subjects). Together, these studies indicate that null objects are not a unidirectional phenomenon, that is, they are not limited to a particular L1/L2 combination.

In the case of L2 Spanish, one of the earliest studies to document null objects is Andersen (1983), who monitored the linguistic development of Anthony, an adolescent boy acquiring Spanish in a naturalistic context. Anthony produced several sentences with missing objects, as illustrated below:

8) Cuando nueva cosa entraban, pue $\varnothing$ ponemos en cajas o algo así pa' vender cosas ... 'When new thing arrived, well we put $\varnothing$ in boxes or something like that in order to sell things.'

Andersen (1983) suggests that omission of the object is just one of the strategies used by Anthony to compensate for his lack of knowledge of correct clitic form and placement.

VanPatten (1987) examined Andersen's (1983) data and compared it to the performance of a classroom learner studying Spanish. In contrast to 
Anthony (the naturalistic learner), VanPatten's classroom learner never omitted object pronouns. This led VanPatten to suggest an instruction effect that may make learners consciously aware of the importance of complete sentences. From a careful assessment of these two learners, VanPatten (1987: 254) hypothesizes that 'instruction impacts upon omission. Classroom learners tend not to omit surface realizations of verbal arguments.' Although the case studies of Andersen (1983) and VanPatten (1987) are informative, the results are, understandably, not generalizable to the population of L2 learners at large.

Sánchez and Al-Kasey (1999), in an investigation of direct object clitics among first- and second-year university-level learners of Spanish, found that the occurrence of null objects was minimal during oral production, thereby tentatively confirming VanPatten's (1987) hypothesis that classroom learners rarely omit arguments. However, Sánchez and AlKasey also found that L2 learners (as well as native speakers from Peru) accepted null direct objects in a sentence-picture matching task. The authors speculate that this may be the result of interpreting the null direct object as generic. Torres (2003) gathered oral data from learners at the intermediate-mid level of proficiency who were studying abroad in Spain for one semester. Although Torres' analysis focuses on the overuse of lexical NPs in different syntactic positions, her data provide evidence of null objects as well (56 tokens). Nevertheless, these tokens represent a small percentage of the total direct object contexts, ranging from $5 \%$ to $8 \%$.

Bruhn de Garavito and Guijarro-Fuentes (2002) conducted a study to determine if L2 learners would be able to recognize the appropriate contexts for object drop in Spanish. Two groups of learners (English and Portuguese speakers) participated in the study, which involved evaluating grammatical and ungrammatical sentences on a scale of from 1 (totally ungrammatical) to 5 (totally grammatical). Two sets of target sentences tested learners' knowledge of the relationship between clitic pronouns and their antecedents, as well as indefinite object drop (grammatical) and definite object drop (ungrammatical). The remaining sets of sentences targeted subjacency and other types of constraints, which I do not discuss here. Bruhn de Garavito and Guijarro-Fuentes found a high rate of acceptance for indefinite object drop, suggesting that learners know it is a syntactic option in the target language. However, acceptance of definite object drop was higher than expected, especially for the 
group of native English speakers. With a mean acceptance rate above 3 (on the scale of 1-5), it is difficult to conclude that this group of learners categorically rejects definite object drop.

The study by Bruhn de Garavito and Guijarro-Fuentes (2002) was the first systematic study of the null object phenomenon in L2 Spanish. The findings suggest that learners at the intermediate level have indeterminate judgements regarding object drop, although there is some indication that they may treat definite and indefinite referents differently. More judgement data from learners of different proficiency levels is needed to establish whether or not learners entertain the possibility of a null objects in Spanish at some point in the acquisition process.

\section{Theoretical explanations of missing arguments}

Theoretical accounts of missing arguments have been extensively developed on the basis of L1 acquisition data. Although a review of L1 argument omission would be beyond the scope of this article, it is important to mention some key findings with respect to null objects. Numerous studies have demonstrated that children from various language groups omit objects at some point in their development (see Guasti, 1994; Allen, 2000; Uziel-Karl and Berman, 2000; Müller and Hulk, 2001). The rates of omission fluctuate in relation to the target language, the discourse context and the age of the child. All of the studies cited above coincide in that younger children produce more null objects than older ones. In addition, it is noteworthy that children omit more subjects than objects in their early utterances, regardless of the target language. This subject-object asymmetry has been noticed by language acquisition researchers for many years (e.g. Hyams, 1986; Bloom, 1990; Wang et al., 1992; Hyams and Wexler, 1993), and has consequences for both performance and grammatical models of argument omission. In this section, both kinds of models are presented with particular attention to the proposal of Fujino and Sano (2002), who examine null objects in L1 Spanish.

\section{Grammatical accounts}

Grammatical accounts (e.g. Hyams, 1983; 1986; Radford, 1990; Wang et al., 1992) propose that null arguments are represented at the level of competence. In the case of L1 acquisition, such models suggest that 
young children have different grammatical representations than adult speakers, that is, they have empty categories where adult speakers would use overt subjects and/or objects. This perspective developed out of the principles-and-parameters (P\&P) model and incorporated the notion of parameter setting, although more recent work (see Fujino and Sano, 2002) recognizes that parameter resetting is not adequate in explaining the observed differences between child and adult language. The work of Hyams $(1983 ; 1986)$ is representative of early research in the P\&P approach to argument omission. For example, Hyams proposed that young English-speaking children initially rely on an incorrect setting of the null subject parameter. ${ }^{3}$ Specifically, she proposed a default setting of [+ pro-drop], which children will re-set if needed, based on evidence from the input. For children learning English, this parametric switch to [-pro-drop] is triggered by input data that are not analysable by the child's current grammar (i.e. lexical expletive it and existential there).

Recent grammatical accounts of argument omission rely less on the metaphor of resetting, favouring instead the notions of optional spellout and/or incomplete specification of functional features. Fujino and Sano (2002) put forward a grammatical explanation for null objects in L1 Spanish, attributing the null object stage to the optional spell-out of clitic pronouns. Data from three children from the CHILDES database were examined: María (ages $1 ; 7-2 ; 5)$, Koki $(1 ; 7-2 ; 7)$, and Juan $(1 ; 7-2 ; 10$ and $3 ; 5-3 ; 9)$. The analysis confirmed higher rates of null objects during earlier stages of acquisition. For example, Koki's object omissions reach percentages of $50 \%$ from age $1 ; 7$ to $1 ; 9$. Furthermore, the increased use of clitics among all three children coincides with a substantial decrease of null objects. In other words, Fujino and Sano observed a 'trade-off' between the use of clitics and null objects. They argue against a performance explanation, citing two pieces of evidence:

- the existence of null objects in sentence internal position, followed by a locative phrase; and

- the trade-off between clitics and null objects, in conjunction with a constant rate of lexical NPs.

\footnotetext{
3 The references to null subjects are made here because the theoretical models discussed in this section developed primarily as a result of children's subject omissions.
} 
Fujino and Sano cite examples of children's speech such as (9) and reason that if processing difficulties were operative, the child could not have produced the prepositional phrase that appears after the omitted object.

9) Pa que, pa que $\varnothing$ pompe en el coche grande.

'So that, so that (he) puts $\varnothing$ in the big car.'

With respect to the constant rate of lexical NPs in object position, Fujino and Sano argue that if children omitted objects due to performance factors, they would omit lexical NPs as well as clitics.

Although they argue for a purely grammatical account of the null object phenomenon, Fujino and Sano's proposal differs in an important way from earlier work that relied on parameter (re)setting. Specifically, the authors argue that Spanish-speaking children have the correct representation from the beginning (i.e. Spanish being a non-null object language), but nevertheless produce null objects because of some failure at spell-out of clitics. In other words, there is no need for resetting because the null object parameter is correctly set from early on. It is noteworthy, however, that problems with spell-out are generally considered to be a mapping or 'retrieval' problem in the UG literature (Lardiere, 2000; Prévost and White, 2000). As White (2003: 95) explains, 'Even if certain morphological forms have been acquired (that is, entered in the mental lexicon), there may nevertheless be occasions when these are not accessible, for processing reasons.' In the end, by relying on the notion of optional spell-out, the grammatical account of Fujino and Sano concedes that some sort of processing difficulty may be responsible for missing surface inflection.

The grammatical account of Fujino and Sano (2002) is also different from that of Müller et al. (1996) and Müller and Hulk (2001), who account for null objects in children's speech by postulating an empty discourse-connected PRO adjoined to IP. This structure is illustrated in (10) with an example from a German-French bilingual child (Müller and Hulk, 2001: 8).

10) $\left[{ }_{I P} P_{P R O}\left[{ }_{I P}\right.\right.$ Ivar répare $\left.t_{i}\right]$

According to this analysis, the onset of the CP system (e.g. wh- questions and embedded clauses) is responsible for the decline in null objects as a function of age. The early stages of acquisition, however, are characterized 
by a universal pragmatic strategy that licences the empty element, in similar fashion to a Chinese-type grammar (Huang, 1984). Fujino and Sano (2002) provide evidence against this proposal by citing examples of accusative clitics that appear earlier in development than wh- movement and the use of null objects in imperatives. According to Fujino and Sano, the development of the CP system is an independent matter and, therefore, there is no reason to assume that Spanish-speaking children initially begin with a Chinese-type null object grammar.

Clearly, not all grammatical accounts of null objects are identical. Müller and Hulk (2001) subscribe to the movement of an empty category that adjoins to IP, following earlier work by Huang (1984). More recent work by Sánchez $(1999 ; 2002)$ characterizes the acquisition problem as one of learning the relevant phi-features of the head of DP. According to Sánchez, who has argued for the existence of a null pronoun in object position for Spanish (and Quechua), languages impose feature specifications on the null object antecedent. In this way, cross-linguistic differences related to the grammaticality of definite vs. indefinite null objects are accounted for.

Despite these differences, all grammatical accounts share certain characteristics and make similar predictions. First, all grammatical accounts predict a stage of object omission, which is distinguishable from subsequent stages of object suppliance. The criteria for what constitutes a 'stage' are often vague, but usually addressed in terms of rate of omission. For example, Müller and Hulk (2001: 15) note that a rate of $11 \%$ of object omissions among French children is 'too much' to be considered a performance phenomenon. On the other hand, Fujino and Sano (2002) assume that there is no null object stage in child English, citing the omission rate of $10 \%$ reported in Wang et al. (1992) and Hyams and Wexler (1993). In sum, it seems that a substantial rate of omissions (generally more than 10\%) is required in order to posit the existence of a null object stage.

Next, grammatical accounts hypothesize some mechanism (e.g. the development of the CP system) that triggers the decline of object omissions. Traditionally, grammatical models predict an abrupt shift between stages of development, which has been viewed as a major weakness by researchers working outside of the UG paradigm (Allen, 2000). The parametric shift is conceptualized as instantaneous, a position defended 
by Hyams (1994: 298): 'we may ultimately find that the instantaneous model of development is closer to the truth than we have imagined.' Recent grammatical models that do not rely on parameter (re)setting must look to other mechanisms in order to explain what moves learners from one stage to the next.

Finally, grammatical explanations are not intended to explain the variable nature of object omission. As noted by Williams (1988), such models do not tell us why learners omit objects in certain discourse contexts or with certain verbs, while producing pronouns and lexical NPs in others. For example, grammatical models would predict the use of null objects across a wide range of transitive verbs. It would be difficult for a grammatical model to explain frequency effects with certain verbs (e.g. the more frequent omission of objects with ditransitives) or the variable use of both null and overt objects with the same verb by the same learner.

\section{Performance accounts}

Performance accounts maintain that missing arguments are not due to a faulty grammatical representation, but rather to processing factors. Bloom (1990) first proposed that children omit arguments because they have a general difficulty in producing long strings of words. This limitation is observed even when children imitate adult speech. Bloom's proposal stems from examining the distribution of null subjects in English-speaking children; he found that these are more frequently omitted in transitive clauses, i.e. when the VP is longer. In other words, the probability that a constituent will be omitted is directly related to the length of the utterance. Bloom also makes some predictions with respect to the omission of pronominal vs. lexical arguments. Since this processing account is based on the length of the constituent, lexical arguments should be omitted more frequently than pronominal ones. This particular issue has generated much controversy, as discussed at the end of this section.

Valian $(1990 ; 1991)$ adopts a performance account of null arguments given the frequency differences in subject production among Italian- and English-speaking children. Valian's data shows that these two groups of children are quantitatively different from one another from a very young age, showing sensitivity to frequency effects in their respective native 
languages (L1 English children use subjects almost 70\% of the time, compared to $30 \%$ for the Italian group). Valian (1990) concludes that the pro-drop parameter is initially unset and that children establish the correct value by gathering (and parsing) the input for evidence.

Performance accounts (Bloom, 1990; Valian, 1990; Gerken, 1991) do not view argument omissions as a result of an incomplete grammar or incorrect parameter-setting. Instead, these authors cite a number of performance limitations that affect children's early productions. For example, Gerken highlights children's sensitivity to prosodic features and argues that children omit weakly stressed syllables in certain positions, which will lead to the omission of pronominal subjects and unstressed determiners. The case of pronominal forms, however, is an interesting point of disparity. Recall that Bloom (1990) predicts that longer arguments (i.e. lexical ones) impose a greater processing burden and, thus, should be omitted more often. Gerken (1991) and Valian (1991) argue just the opposite: pronominal forms are more difficult for young children to produce than NPs.

The unresolved issue of lexical vs. pronominal forms is one of the main critiques made against performance accounts of argument omission. Proponents of grammatical models (Fujino and Sano, 2002) cite a tradeoff between null and pronominal arguments, with the rate of lexical NPs remaining constant. Likewise, Hyams (1994) claims that performance accounts are not able to capture the relevant proportions of pronominal, null and lexical NPs. In addition, performance accounts alone are unlikely to explain the subject-object asymmetry, that is, the finding that objects are omitted less frequently than subjects in L1 acquisition, irrespective of native language.

Performance models posit difficulties in computation rather than a deficit in representation. The specific predictions of any such model would include the lack of a clearly definable null object stage. Instead, learners' production would be characterized by considerable variability (i.e. inconsistent use). We would also expect to find null objects at various levels of proficiency, assuming that processing can become difficult for even more advanced speakers. In addition, a performance model would predict that certain types of transitive verbs might cause a greater processing burden than others. In other words, there may be frequency effects within the class of transitive verbs. 


\section{Elicitation methods}

A multiple-task design was chosen for this study in order to obtain a more comprehensive picture of null objects in learner language. The use of multiple assessment tasks is common practice in SLA research. As Chaudron (2003: 763) points out, utilizing a variety of data collection procedures is not only feasible, but desirable, in order to 'obtain the best sample of learners' performance potential'. However, since this study presents data from what are traditionally seen as two distinct sources (oral production tasks and a grammaticality judgement task), it is necessary to examine previous findings regarding the relationship between these two methodologies. Following Birdsong (1989), Ellis (1991), Gass (1994) and others, I assume that grammaticality judgement tasks (GJT) provide a measure of metalinguistic performance. Oral production tasks, in contrast, provide more naturalistic (i.e. contextualized) contexts that elicit longer stretches of discourse and a potentially wide range of grammatical structures.

Cross-task comparisons between GJTs and other kinds of tasks have been carried out, with a handful of studies focusing on the relationship between oral production and grammaticality judgements. Some researchers have suggested that learners' judgements mirror their oral production. For example, Chaudron's (1983) thorough review of existing research led him to the conclusion that metalinguistic judgements in native and non-native speakers tend to be corroborated by other measures of performance. Similarly, Leow (1996) presents an empirical study that finds a correlation between performance on grammaticality judgement and production tasks. The learners, who were enrolled in first-semester Spanish courses, were asked to complete three tasks that targeted nounadjective agreement: two production tasks (one oral and one written) and a GJT. Leow found a significant relationship between the production tasks and the GJT, both at the beginning and end of the semester (the correlations yielded $r$ values above .50 in all cases). Furthermore, the correlation between the written production task and the GJT was stronger than the correlation between the GJT and the oral task. Consequently, Leow suggests that grammaticality judgement tasks may be more predictive of performance on written production tasks.

Nevertheless, many SLA studies have cast doubt on the possible parallel between metalinguistic judgements and oral production. For example, 
Ellis (1991: 166) affirms there is 'ample evidence to suggest that learners perform quite differently in a grammaticality judgement task and in oral production.' Ellis and Rathbone (1987) found non-significant correlations between beginning learners' spontaneous production of word order combinations in German and their performance on a grammaticality judgement task designed to measure the same word-order rules. Christie and Lantolf (1992), in their longitudinal investigation of null subjects in L2 Italian, discuss the noteworthy improvement of one participant's oral production in relation to his/her unchanging performance on a grammaticality judgement task (for a thorough discussion of this study and its methodological limitations, see Gass, 1994). Isabelli (2004) carried out a longitudinal study of null subjects (and related properties) in Spanish using both grammaticality judgement data and oral narratives. Although Isabelli did not compute correlations to examine the relationship between the two tasks, her results indicate some divergence. Although the learners were already performing at ceiling levels on the GJT in terms of null pronouns and expletives at the onset of the study, their use of null subject pronouns increased significantly in oral production over a nine-month period. However, when examining the property of subject-verb inversion, Isabelli found that the naturalistic data from the oral interviews paralleled the GJT analysis.

In the particular case of null objects, there is an important motivation for employing both types of methodologies. The oral production tasks used in this study (see next section) provide learners with numerous, meaningful opportunities to produce direct objects, but learners may encode the direct object participant in a number of ways. Simply put, some learners may never produce null objects because they prefer other forms. This is precisely the kind of situation in which a more controlled, experimental task such as a grammaticality judgement becomes useful. If null objects are as infrequent in oral production as VanPatten (1987) originally predicted, the GJT will provide an additional (and possibly different) measure of this type of argument omission.

\section{The present study}

\section{Participants}

The participants were $50 \mathrm{~L} 2$ learners of Spanish who were enrolled in various Spanish language courses at a large public university in the USA. 
Together, these 50 learners comprised four proficiency groups (beginner, intermediate, high intermediate and advanced) based on their institutional status, prior classroom exposure to Spanish and time spent abroad. Each group had 12 participants, with the exception of the advanced group $(n=14)$. Participants were accepted for the study only after being screened for a number of background factors: all were native English speakers and all reported English as the only language spoken in their household. In addition, potential participants were excluded from the study if they had formally studied another language besides Spanish for three years or more. None of the participants had any previous exposure, either formal or informal, to an object drop language (e.g. Japanese).

In terms of prior exposure to Spanish, the participants in the beginner group were finishing their third quarter of language study, in addition to having taken the first two quarters of Spanish at the university. The intermediate students were finishing their second year of Spanish language instruction, without the benefit of having studied abroad. The high intermediate and advanced students had all studied Spanish abroad, with an important difference between the two groups: the former had been on short-term programs (2-3 months), whereas the latter group consisted solely of Spanish majors who had spent an entire academic year in a Spanish-speaking country. ${ }^{4}$

\section{Methodology}

Oral production data were gathered by means of four elicitation procedures: a storybook narration, a structured interview and two video narration tasks. A popular children's picture book (dePaola's Pancakes for Breakfast , 1978) was chosen for the storybook narration task because the plot involves many inanimate objects, thus providing natural contexts for the expression of direct objects (both lexical and pronominal). In order to facilitate language production during the storybook narration task, the participants were given a list of vocabulary items and instructions (see Appendix 1). These items were glossed because they were central

\footnotetext{
${ }^{4}$ The participants from the high-intermediate and advanced groups had studied in a variety of countries including Spain, Mexico, Chile, Honduras and Argentina. There was one learner (P48) who spent a year in Ecuador and thus had exposure to a contact variety of Spanish. However, this learner produced no tokens of null objects in the oral tasks and never accepted them on the GJT.
} 
to describing certain events and, furthermore, pilot testing suggested that these lexical items might be unknown to some of the participants. Participants were given planning time to study the vocabulary list and scan the pictures in order to familiarize themselves with the plot.

The second oral task was a structured interview, modelled after previous research on Spanish clitics (VanPatten and Sanz, 1995; Sanz, 1997). The interview consists of carefully phrased questions that are expected to elicit the use of (pronominal) direct objects in the response. The interview format is illustrated below:

11) Question: ¿Qué hizo el niño con el libro?

'What did the boy do with the book?'

Response: Lo puso en la canasta.

'He put it in the basket.'

In the present study, the context for the structured interview procedure was the picture book that the participants had just been asked to narrate. The complete list of questions used in the structured interview procedure can be found in Appendix 2.

The two remaining oral tasks involved the narration of two silent video clips. In similar fashion to VanPatten and Sanz (1995) and Sanz (1997), the participants were given a list of English-Spanish equivalents before viewing each video clip (see Appendix 3 and Appendix 4). The video clips were shown twice, just like in the above-mentioned studies. However, in the present study the participants were asked to narrate the events that were happening on the screen during the second viewing. Accordingly, this can best be described as a simultaneous video narration task, while the VanPatten and Sanz (1995) procedure is a video retelling.

The grammaticality judgement task (GJT) was administered after the four oral tasks had been completed. It can be described as a standard grammaticality judgement task (compare Davies and Kaplan, 1998) because participants were given as much time as needed to complete it. The task consisted of 24 target sentences and 24 distracters, with an even number of grammatical and ungrammatical sentences. It was designed partially on an instrument developed by Hedgcock (1991) to measure knowledge of key grammatical structures in Spanish. Participants were asked to evaluate the sentences on a three-point scale (correct, incorrect or 'not sure'). While such a scale does not allow for a separate analysis 
of judgement accuracy and judgement confidence (Sorace, 1996), it does give the learner the option of not rendering an either-or judgement. ${ }^{5}$ As part of the GJT, participants were instructed to correct the perceived errors in sentences that they judged to be incorrect. The rationale for including such a component was to isolate participants' responses that were based upon element(s) peripheral to the focal syntactic properties of the sentence.

The grammatical sentences all contained correct use of third-person direct object clitics in anaphoric contexts. Half of the grammatical sentences were coordinated structures and other half consisted of short question-answer dialogues. The ungrammatical sentences included three types of structures: null objects with specific referents, ${ }^{6}$ wrong verb-clitic word order, and lack of clitic doubling with strong pronouns. Sentences with incorrect clitic placement and lack of clitic doubling were included because they are common learner errors, as reported in the literature on the acquisition of clitics (see Lee, 2003). There were four items for each type of structure. Examples of the grammatical and ungrammatical target sentences are given in Table 1.

All participants met individually with the researcher for approximately one hour on two separate occasions. Participants were asked to perform the storybook and structured interview tasks during the first session; the video narrations and grammaticality judgement task were completed during the second meeting.

\section{Data analysis}

The oral data were recorded, transcribed and then analysed with specific attention paid to the forms that appeared in DO contexts. ${ }^{7}$ These were coded according to six categories, partially based on the categorization

\footnotetext{
${ }^{5}$ Sorace (1996) discusses the disadvantages of eliciting absolute judgements from L2 learners, favouring instead alternative techniques such as ranking scales and magnitude estimation. While the three-point scale has obvious weaknesses, scales including more than three points (i.e. 1 to 5) present the additional complication of how to interpret intermediate scores.

${ }^{6}$ Sentences with grammatical null objects (i.e. with mass nouns and bare plurals) were not included in the experiment. Thus, the results are not directly comparable to those of Bruhn de Garavito and Guijarro-Fuentes (2002). The purpose of including the GJT in the current study was not to compare responses on different types of null objects, but rather to see if learners accept the kinds of sentences they produce in oral tasks.

${ }^{7}$ The oral corpus was coded by the researcher in consultation with two native speakers of Spanish who examined all cases of null objects. Only the null objects identified as such by both native speakers are included in the analysis.
} 
Table 1 Grammaticality judgement task target structures

\begin{tabular}{|c|c|}
\hline Sentence type & Example \\
\hline Coordinated structures $(k=6)$ & $\begin{array}{l}\text { Compré el libro pero luego lo vendí. } \\
\text { 'I bought the book but later sold it.' }\end{array}$ \\
\hline Question-answer dialogues $(k=6)$ & $\begin{array}{l}\text { ¿Qué hiciste con el pastel? } \\
\text { Lo puse en el refrigerador. } \\
\text { 'What did you do with the cake? } \\
\text { I put it in the fridge.' }\end{array}$ \\
\hline${ }^{*}$ Null objects $(k=4)$ & $\begin{array}{l}\text { Ellos compraron la cerveza y } \\
\text { pusieron en el refrigerador. } \\
\text { 'They bought the beer and put in } \\
\text { the fridge.' }\end{array}$ \\
\hline *Wrong verb-clitic order $(k=4)$ & $\begin{array}{l}\text { Pilar termina la tarea y pone la en } \\
\text { su mochila. } \\
\text { 'Pilar finishes her homework and } \\
\text { puts it in her backpack.' }\end{array}$ \\
\hline${ }^{*}$ Strong pronouns w/o clitic double $(k=4)$ & $\begin{array}{l}\text { La profesora ayuda a él con la tarea. } \\
\text { 'The professor helps him with the } \\
\text { homework.' }\end{array}$ \\
\hline
\end{tabular}

used by Torres (2003) and findings from pilot testing: lexical NP, DO clitic, null object, anaphoric se, strong pronoun and clause. These six categories are illustrated in Table 2 with relevant examples from the corpus, each of which is labelled according to participant number (P1-P50), level ( $\mathrm{B}=$ beginner, $\mathrm{I}=$ intermediate, $\mathrm{HI}=$ high intermediate, $\mathrm{A}=$ advanced $)$ and elicitation task $(\mathrm{ST}=$ storybook, $\mathrm{SI}=$ structured interview, $\mathrm{V} 1$ and $\mathrm{V} 2=$ video tasks).

The categories in Table 2 account for all of the various NP types produced by L2 learners in direct object contexts. Lexical NPs include definite, indefinite and bare nouns, as well as demonstrative pronouns. The category of direct object clitics includes the accusative forms lo, la, los, $l a s$, as well as the use of $l e(s)$ in direct object contexts, a type of overgeneralization that has been previously documented in L2 speech (Zyzik, 2006). Inaccurate usage of direct object clitics in which the wrong form was supplied (i.e. incorrect marking of gender or number) or was improperly placed were also included. Null objects were operationalized as the occurrence of a zero form in a non-partitive context involving an obligatorily transitive verb. Omission of se in reflexive and reciprocal contexts is not included here because it constitutes a different type of error. ${ }^{8}$ The category of anaphoric se describes the use of the reflexive/middle marker

\footnotetext{
${ }^{8}$ It is a distinct problem because it can often be explained by transfer from English, given that English does not morphologically encode middle voice.
} 
Table 2 Linguistic forms used in direct object contexts

\begin{tabular}{|c|c|c|}
\hline Category & Example from corpus & $\begin{array}{l}\text { Participant } \\
\text { details }\end{array}$ \\
\hline Lexical NP & Ella quiere [panqueques] para desayuno. & $\mathrm{P} 12, \mathrm{~B} ; \mathrm{ST}$ \\
\hline DO clitic & $\begin{array}{l}\text { Vio a los ingredientes que necesitaba y } \\
\text { empezó a sacar[las]. }\end{array}$ & P33, HI; ST \\
\hline Null object & $\begin{array}{l}\text { Ella está pensando toda la mañana sobre } \\
\text { su desayuno, y su perro y gato }[\varnothing] \\
\text { destruyen. }\end{array}$ & P21, I; ST \\
\hline Anaphoric se & $\begin{array}{l}\text { Después ella tiene la mantequilla y [se] } \\
\text { pone encima de la mesa con los } \\
\text { otros ingredientes. }\end{array}$ & P26, HI, ST \\
\hline \multirow{2}{*}{$\begin{array}{l}\text { Strong pronoun } \\
\text { Phrasal complement }\end{array}$} & Las gallinas miren [ella]. & $\mathrm{P} 1, \mathrm{~B} ; \mathrm{ST}$ \\
\hline & $\begin{array}{l}\text {... descubre[que el perro y el gato han } \\
\text { echado todo al piso]. }\end{array}$ & P39, A; ST \\
\hline
\end{tabular}

se in contexts where accusative clitics would be used by a native speaker of Spanish. Strong pronouns (e.g. él, ella) are sometimes used by L2 learners in place of the corresponding accusative clitics, constituting a violation of Spanish syntax. Finally, direct objects can take the form of clausal complements. Infinitival complements such as quiere [comer la galleta] 'he wants to eat the cookie' were considered to be manifestations of clause reduction (Moore, 1996), and the direct object of the lower verb (in this case, la galleta) was coded appropriately.

Prepositional objects, both grammatical and ungrammatical, are not included in the analysis. For example, the verb buscar 'to look for' takes a direct object in Spanish. However, L2 learners often use this verb in an argument frame that resembles their L1 by adding a preposition (most often para 'for'). The same is true for the verb pedir 'to ask for'. Thus, complements that would normally be direct objects in Spanish sometimes appear in the corpus as part of prepositional phrases, and are not included in the present analysis.

The scoring of grammaticality judgement task proceeded as follows: participants received 2 points for correctly accepting a grammatical sentence and 0 points for rejecting it. For the ungrammatical items, participants received 2 points for accepting the sentence and 0 points for rejecting it. The 'not sure' responses were assigned 1 point given the impossibility of determining the motivation behind the learners' uncertainty. ${ }^{9}$

\footnotetext{
${ }^{9}$ There were a minimal number of 'not sure' responses, which coincides with the findings reported in Ellis (1991).
} 
In addition, learners' responses were further examined for locus of ungrammaticality. For example, item 33 on the GJT task (below) was rejected by some of the participants because they rejected the use of compro (simple present) to express the near future. Many of the learners who rejected this sentence crossed out 'compro' and replaced it with 'voy a comprar' or 'compraré' (periphrastic and morphological future forms), but still left the object slot empty.

12) Cristina: ¿Compraste el boleto de avión?

'Did you buy the plane ticket?

Javier: No, todavía no. Pero compro hoy.

'No, not yet. But I will buy today.'

Since the interest here was to assess whether or not learners noticed the missing object, such responses were coded as 'acceptance' of the ungrammatical sentence.

\section{Results}

\section{Oral production data}

The oral production tasks elicited a considerable number of direct object contexts $(k=4070)$. Table 3 shows the distribution of the direct objects forms that appeared in those contexts. Each row shows two figures: the raw tokens and the percentage (i.e. the ratio of tokens in relation to the total number of DO contexts produced by that group). As illustrated in Table 3, lexical NPs are by far the most frequent forms that appear in direct object position. This is not surprising given that the same pattern holds in native speaker speech: in a corpus of spoken Spanish, $72 \%$ of objects

Table 3 Distribution of direct object forms (percentages in parentheses)

\begin{tabular}{|c|c|c|c|c|c|c|c|c|}
\hline \multirow[b]{2}{*}{ Lexical NP } & \multicolumn{2}{|c|}{ Beginner } & \multicolumn{2}{|c|}{ Intermediate } & \multicolumn{2}{|c|}{$\begin{array}{l}\text { High } \\
\text { intermediate }\end{array}$} & \multicolumn{2}{|c|}{ Advanced } \\
\hline & 775 & (91.6) & 765 & $(82.0)$ & 710 & $(73.0)$ & 946 & $(72.0)$ \\
\hline DO clitic & 5 & 10 & 83 & 18 & 17 & (18 & 29 & (2) \\
\hline Null object & 31 & (3.7) & 42 & (4.5) & 29 & (3.0) & 16 & (1.2) \\
\hline Anaphoric se & 12 & (1.4) & 11 & (1.2) & 17 & (1.7) & 23 & (1.7) \\
\hline Strong pronoun & 16 & (1.9) & 6 & $(0.6)$ & 12 & (1.2) & 0 & $(0.0)$ \\
\hline Phrasal complement & 7 & (0.8) & 27 & (2.9) & 30 & (3.1) & 35 & (2.6) \\
\hline Total contexts & 846 & $(100.0)$ & 934 & $(100)$ & 973 & $(100.0)$ & 1317 & $(100.0)$ \\
\hline
\end{tabular}


appear as full NPs (Bentivoglio, 1992). In this sense, the learners from the high intermediate and advanced group pattern perfectly with native speakers. Furthermore, the learners in the advanced group display exactly the same percentage of clitic use as reported by Bentivoglio for native speakers: $23 \%$. Additional observations that can be highlighted from Table 3 include the almost complete lack of direct object clitics at the beginner level, the interesting overgeneralization of se to anaphoric contexts, and the very low rate of ungrammatical strong pronoun use across all groups. ${ }^{10}$

Null objects, the focus of this article, occurred 118 times in the corpus, which accounted for $2.9 \%$ of the total direct object contexts. The percentage of null objects produced by each individual learner varies greatly (range: $0-16.4 \%$ ), with a mean of $3.14 \%$ and standard deviation of 3.8 . The tokens of null objects were distributed among learners from all four groups, albeit not evenly. A one-way analysis of variance reveals that the differences between groups are not significant $(F(3,46)=1.665, p>.05)$. The descriptive statistics for the null object tokens are presented below in Table 4. Further examination of the data suggests that null objects occur more commonly in particular discourse contexts. The distribution of null objects is summarized in Table 5. Table 5 clearly indicates that null objects are most prevalent in conjoined structures, as illustrated in (13). Such examples constitute $66 \%$ of the total 118 tokens.

13) El hombre abraza la mujer y él quita su chaqueta y $\varnothing$ tira en el sillón.

'The man hugs the woman and he takes off her coat and throws $\varnothing$ on the chair.'

Table 4 Descriptive statistics for null object tokens in oral production

\begin{tabular}{|c|c|c|c|c|c|c|c|c|}
\hline & \multicolumn{2}{|c|}{ Beginner } & \multicolumn{2}{|c|}{ Intermediate } & \multicolumn{2}{|c|}{$\begin{array}{c}\text { High } \\
\text { intermediate }\end{array}$} & \multicolumn{2}{|c|}{ Advanced } \\
\hline & Total & $\begin{array}{l}\text { Mean } \\
\text { (SD) }\end{array}$ & Total & $\begin{array}{l}\text { Mean } \\
\text { (SD) }\end{array}$ & Total & $\begin{array}{l}\text { Mean } \\
\text { (SD) }\end{array}$ & Total & $\begin{array}{l}\text { Mean } \\
\text { (SD) }\end{array}$ \\
\hline $\begin{array}{l}\text { Tokens of } \\
\text { null objects }\end{array}$ & 31 & $\begin{array}{c}2.58 \\
(2.67)\end{array}$ & 42 & $\begin{array}{c}3.50 \\
(2.71)\end{array}$ & 29 & $\begin{array}{c}2.41 \\
(3.60)\end{array}$ & 16 & $\begin{array}{c}1.14 \\
(1.70)\end{array}$ \\
\hline
\end{tabular}

\footnotetext{
${ }^{10}$ For reasons of space, I do not elaborate on these issues here. This study forms part of a larger study on the acquisition of clitic pronouns in L2 Spanish (Zyzik, 2004).
} 
Table 5 Discourse contexts in which null objects appear

\begin{tabular}{lcclcc}
\hline Discourse context & Beginner & Intermediate & $\begin{array}{l}\text { High } \\
\text { intermediate }\end{array}$ & Advanced & Total \\
\hline $\begin{array}{l}\text { Conjoined } \\
\text { Topic established }\end{array}$ & 27 & 27 & 17 & 7 & 78 \\
$\quad$ by interlocutor & & 6 & 6 & 2 & 17 \\
$\begin{array}{l}\text { After preposition } \\
\quad \text { para }\end{array}$ & 0 & 3 & 2 & 4 & 9 \\
$\begin{array}{l}\text { Inter-sentential } \\
\text { Double object }\end{array}$ & 1 & 3 & 2 & 2 & 8 \\
Left-dislocated NP & 0 & 2 & 1 & 1 & 4 \\
\hline
\end{tabular}

Null objects were also frequently found in the transcripts of the structured interview, in which the researcher establishes the discourse topic in the question, as in example (14).

14) Y aquí ¿qué hace la mujer con el libro?

$\varnothing$ Saca de la estante.

'And here what does the woman do with the book?'

'She takes $\varnothing$ off the shelf.'

Together, conjoined clauses and questions that established a discourse topic account for nearly $81 \%$ of the occurrence of null objects. Intersentential null objects, as in example (15), were rare, but note that the null object refers to the discourse topic (Tico).

15) También limpia sus ojos. Tico está muy tranquilo con eso. Después $\varnothing$ saca de la bañera y Carmen seca Tico un tiempo más.

(P28-HI; V2)

'She also cleans his eyes. Tico is very calm with this. Afterwards, she takes $\varnothing$ out of the tub and Carmen dries Tico one more time.'

There were only 4 tokens of DO omission in double object contexts (i.e. with ditransitive verbs such as dar 'to give'). Consider the example in (16).

16) Saca una galleta y le $\varnothing$ da a Tico.

'She takes out a cookie and gives $\varnothing$ to Tico.'

(P13-HI; V2)

The learner in (16) has omitted accusative clitic la in the second clause, which in this context would require the combination se la $\mathrm{da}$ 'she gives it to him'. Instead, the learner opts for the simplified form le da 'gives her/ him' thereby including the dative but omitting the accusative. Interestingly, the use of null direct objects in ditransitive constructions has been 
documented in native speaker Spanish by Kany (1945), Suñer and Yépez (1988) and, most recently, by Company (2001), who proposes that it is part of a diachronic process of the dative displacing the accusative.

All utterances containing null objects were further analysed in order to determine if certain verbs promoted the omission of the object. The results reveal that the verb most frequently associated with null objects is poner 'put' $(k=43)$. The verb echar 'pour', whose argument structure is identical to poner, also promoted the use of null objects $(k=11)$. Tirar 'throw', which takes an optional locative complement, occurred 12 times with a missing object. Since these three verbs account for more than $50 \%$ of the total occurrences of null objects, it is possible that this is not coincidental, but rather the result of some feature that poner, echar and tirar have in common. I return to this issue in the discussion. The remaining tokens of null objects occurred with verbs such as secar 'dry', comprar 'buy', enjuagar 'rinse' and tapar 'cover.'

Another issue that arises with regards to the use of null objects with certain verbs is the question of variability. In other words, when a learner omitted the object with a particular verb, did he/she do so consistently? The answer to this question is unequivocally negative. The transcripts of the oral data provide numerous examples of variable use of null objects within the speech of individual participants. For example, consider the use of secar 'to dry' by P26, a learner from the high intermediate group.

17) Y después ella quita Tico de la bañera y $\varnothing$ seca más.

'And later she removes Tico from the tub and dries $\varnothing$ some more.'

(P26-HI; V2)

18) Ella usa un secador para secar el pelo y las orejas y el cuerpo. 'She uses a hair dryer to dry the hair and the ears and the body.'

(P26-HI; V2)

The examples above illustrate how the same transitive verb, secar, is used first with a null object, but then with a lexical NP almost immediately afterwards (in the same oral task). Another example comes from $\mathrm{P} 46$, an advanced learner who uses the verb coger with both pronominal and lexical NPs on twelve occasions, but then omits the object in response to a question in the structured interview.

19) ¿Y aquí qué hace la mujer con el libro? $\varnothing$ Coge del estante. 
'And here, what does the woman do with the book?'

'She takes $\varnothing$ off the shelf.'

As previously mentioned, null objects in contact varieties of Spanish generally have non-human referents (Schwenter, 2006). The data presented here were analysed to determine if this tendency holds for L2 learner language. Since one of the video tasks presented a scene of a dog who was being bathed by his owner, this presented an additional complication. When considering the distribution of null objects between animate and inanimate referents, there were 84 tokens referring to [-animate] and 34 referring to [+animate]. However, of those 34 , the large majority referred to the dog in the second video task. If the analysis is done in terms of the feature [+human] vs. [-human], then the trend is exceptionally clear: $97 \%$ of the null objects in the data have non-human referents.

An interesting feature of the oral data is the presence of self-corrections. There were many cases in which a learner initially employed a null object, but then immediately self-corrected to include the full NP or, in some cases, a clitic.

20) ¿Qué hace con la harina?

Ella $\varnothing$ echa. Echa la harina en el recipiente.

'What does she do with the flour?'

'She pours $\varnothing$. She pours the flour in the bowl.'

Self-corrections such as (20) never occurred in the opposite direction, that is, a learner using the full NP and then correcting himself by omitting the object. All of the self-corrections began with a null object, which was later remedied by means of a full NP or a clitic pronoun. Such cases of self-repair were coded twice: once as a null object and once as a lexical NP or DO clitic.

\section{Grammaticality judgement data}

The mean scores for the grammatical and ungrammatical sentences were tabulated out of a total of 24 points. Means approximating 24 indicate acceptance while means approximating 0 indicate rejection. The descriptive statistics for all four groups of learners are presented in Table 6.

A review of Table 6 shows that all learners, regardless of proficiency level, were extremely accurate in judging the grammatical sentences. In contrast, the responses on the ungrammatical items point to a clearer 
Table 6 Summary table of mean scores on grammaticality judgment task (SD in parentheses)

\begin{tabular}{lll}
\hline & Ungrammatical items & Grammatical items \\
\hline Beginner & $19.25(4.13)$ & $20.08(3.02)$ \\
Intermediate & $8.83(3.40)$ & $23.08(1.08)$ \\
High intermediate & $9.08(5.17)$ & $23.33(1.23)$ \\
Advanced & $3.43(2.62)$ & $23.71(0.61)$ \\
\hline
\end{tabular}

differentiation between groups. A two-way repeated measures ANOVA was conducted to determine whether learners treated the two types of experimental sentences differently. The within-subjects factor was sentence type (grammatical vs. ungrammatical) and the between-subjects factor was group (beginner, intermediate, high-intermediate, advanced). Results indicate a significant main effect for sentence type $F(1,46)=367.4, p<.001$, with grammatical items $(M=22.55)$ being accepted more than ungrammatical ones $(M=10.14)$, a significant main effect for group $F(3,46)=20.8, p<.001$, and a significant type by group interaction $F(3,46)=40.819, p<.001$. Post-hoc Tukey tests indicated that within the ungrammatical condition, there were significant differences between the beginners and the other three groups $(p<.001)$ as well as between the advanced learners and the other groups $(p<.005)$. In the grammatical condition, however, only the beginners were significantly different from the other three groups $(p<.005)$.

The responses on the ungrammatical items were further analysed according to construction type. The distribution of acceptance on these items is presented graphically in Figure 1. As shown in Figure 1, the advanced learners' mean acceptance rate of 3.43 is attributed primarily to one kind of ungrammatical construction: sentences with tonic pronouns and no clitic double. Their acceptance of null objects, which constitute the focus of this study, was minimal. A $3 \times 4$ repeated measures ANOVA was conducted to see whether the differences between types of ungrammatical sentences (null, V-clitic order and tonic pronoun without doubling) were significant. The analysis reveals a main effect for sentence type $F(2,92)=11.64, p<.001$, a main effect for group $F(3,46)=37.28$, $p<.001$, and a type by group interaction $F(6,92)=3.92, p<.005$. The results on the ungrammatical sentences containing null objects are presented in Table 7 . Note that these means were tabulated out of 8 . 


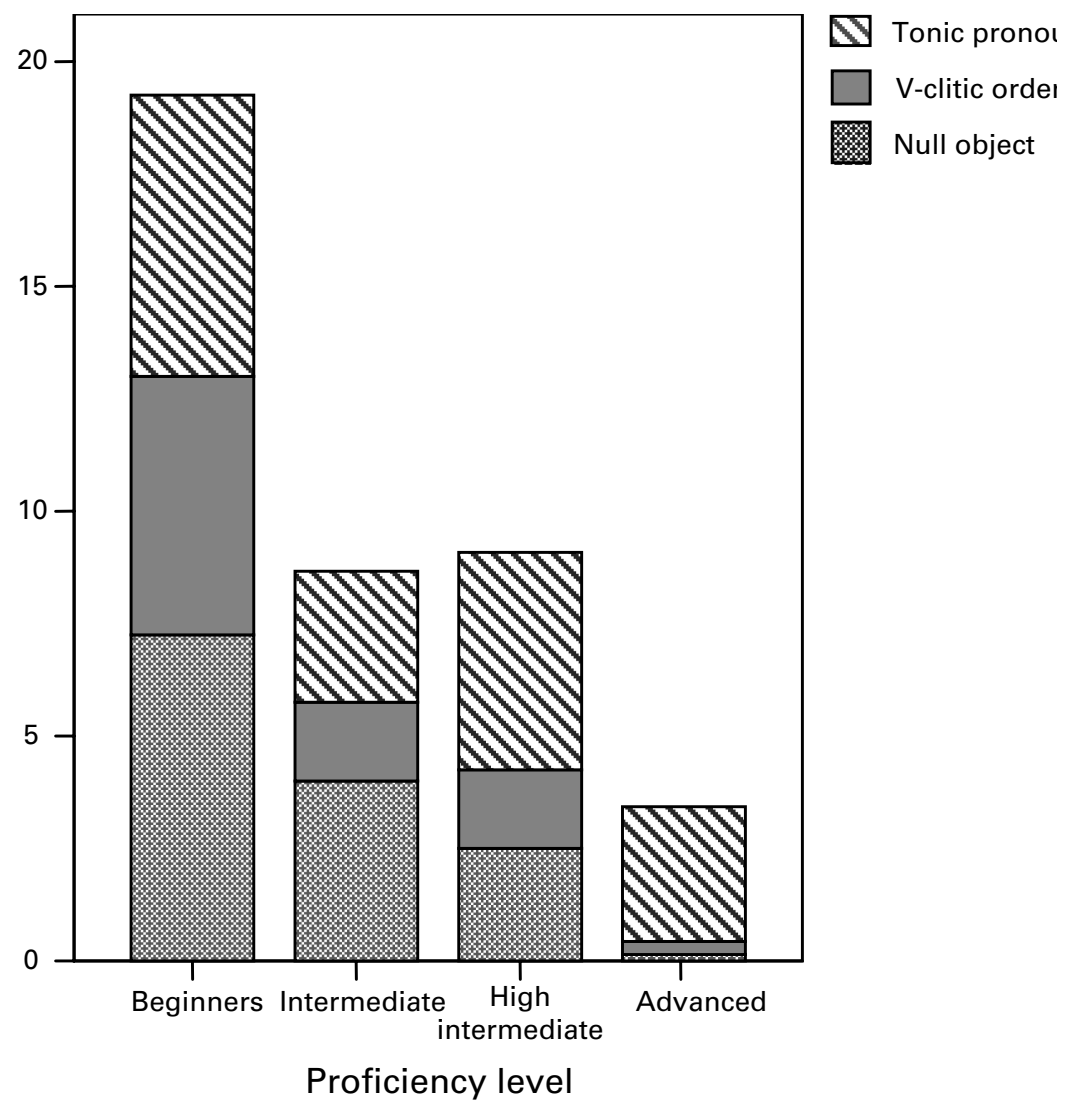

Figure 1 Distribution of acceptance on ungrammatical items

When considering the acceptance of null objects as a dependent variable, the data reveal significant differences between the beginners and the other three groups $(p<.001)$ as well as between the advanced learners and other groups $(p<.005)$. Once again, the difference between the intermediate and high-intermediate learners was not significant $(p>.05)$.

\section{Correlation between GJT and production data}

One of the goals of the present study is to determine if there is a relationship between learners' performance on the written GJT and their oral production. In other words, if learners accept null objects on a test of grammatical intuitions, do they also produce them? If learners produce 
Table 7 Mean scores on ungrammatical items containing null objects (SD in parentheses)

\begin{tabular}{lll}
\hline & Mean & SD \\
\hline Beginner & 7.25 & 1.055 \\
Intermediate & 4.00 & 2.49 \\
High intermediate & 2.50 & 1.93 \\
Advanced & 0.14 & 0.53 \\
\hline
\end{tabular}

null objects, do they necessarily accept them? Correlations were computed in order to answer this question. If performance on the two tasks is related, we would expect this to be a positive correlation (i.e. a higher number of null objects in the oral tasks will be proportional to a higher acceptance rate on the GJT).

Before the correlation was computed, the raw tokens of null objects from the oral tasks for each individual were converted into percentages: the number of null objects produced was divided by the total number of direct object contexts. For example, $\mathrm{P} 46$ produced six null objects in the oral tasks out of a total 102 DO contexts, meaning that $5.9 \%$ of this participant's direct objects were null. Likewise, a percentage was calculated for each learner's performance on the null object portion of the GJT. This allowed the 'not sure' responses to be discarded from the calculation. For example, P15 accepted 2 sentences with null objects, rejected one, and marked 'not sure' for one. This yields an acceptance rate of $66.7 \%$.

A correlation between these two variables - percentage of null objects produced in the oral tasks and percentage of acceptance on the GJT was positive and statistically significant, $r(49)=.37, p<.05$. As shown in Figure 2, as the acceptance of null objects on the GJT increases, the percentage in the oral tasks increases as well. Nevertheless, there could be a third variable that influences both the percentage of null objects produced and the percentage of null objects accepted on the GJT. In that case, this third variable (i.e. a confounding variable) would produce a spurious correlation. The most likely third variable in this case is the individual learner's production of direct object clitics. If we assume that null objects in L2 Spanish are in fact clitic omissions (for further discussion of this point, see next section), then null objects 'compete' with direct object clitics in the interlanguage grammar. It is reasonable to hypothesize that frequent use of direct object clitics is associated with 


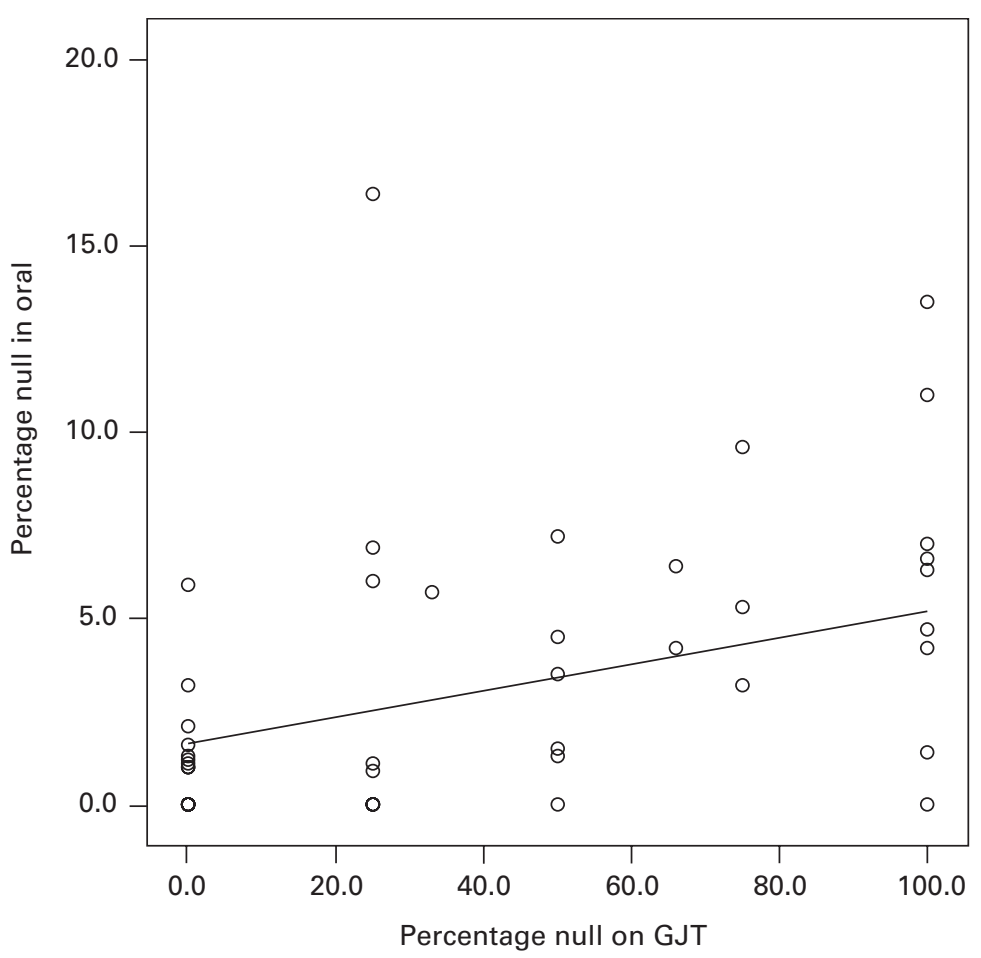

Figure 2 Correlation between null objects in oral tasks and GJT

minimal use of null objects. A correlation was computed to test this hypothesis. The two variables - percentage of null objects in the oral tasks and percentage of DO clitics in the oral tasks - yield the expected negative correlation, $r(49)=-.45, p<.01$. Furthermore, it is reasonable that learners who produce a high percentage of DO clitics are less likely to accept null objects on the GJT. A correlation between these two variables yields a very strong negative correlation, $r(49)=-.73$, $p<.01$. These statistically significant negative correlations indicate that there is in fact a third variable to consider: learners' production of DO clitics. Given this finding, a partial correlation was computed in order to control for the effect of DO clitic production. If we control for DO clitic production, we find that the correlation between the two original variables (percentage of null objects accepted on the GJT and percentage of null objects in the oral tasks) is reduced to near zero, $r(47)=.071$, not significant. 


\section{Discussion}

\section{Frequency and distribution of null objects in oral production}

Null objects were not entirely absent from the oral corpus as VanPatten (1987) had predicted for classroom learners but, admittedly, the relative frequency of this type of argument omission is low. Considering the large number of direct object contexts $(k=4070)$ elicited during the four oral tasks, the 118 tokens of null objects amount to only $2.9 \%$ of the total. The distribution of these tokens is also worthy of note. The data reveal that null objects in second language production are restricted to pragmatically appropriate contexts, that is, when their referents are highly accessible and indicate topic continuity (Givón, 1984; Ariel, 1990). Recall that the large majority of null objects occurred in coordinated structures and in response to questions, which means that the referent was present in the clause immediately preceding the occurrence of the null object. Furthermore, almost all of the null objects in the corpus had non-human referents. These two observations regarding the distribution of null objects in L2 Spanish coincide with the empirical research on contact varieties of Spanish (compare Schwenter, 2006).

In addition to the discourse distribution of null objects, the data reveal the frequent use of null objects with three-argument verbs like poner 'put' and echar "pour.'"11 This suggests that we should not only consider the larger discourse context, but also verb type as a factor that may promote null objects. Three-argument verbs like poner actually transmit four pieces of information: the agent, the action, the object and the location. Given that connected discourse consists of both new and presupposed information, an utterance containing the verb poner will generally exclude certain participants from the scope of assertion (see Givón, 1984). In response to a question like 'What does she do with the eggs?' (included in the structured interview task), there are two pieces of information that must be included in the scope of new information in order to transmit a comprehensible message: the action and the locative complement. Thus, when an L2 learner uses poner with an NP antecedent that is easily recoverable,

\footnotetext{
${ }^{11}$ These verbs were particularly frequent in the corpus, given the content of the oral tasks. However, the most frequently used transitive verb in the corpus, tener, 'to have' rarely appeared with a missing object.
} 
it is logical that the object often gets dropped in favour of more essential information: the locative complement.

To summarize, we may reasonably conclude that the null objects produced by these L2 learners are in fact clitic omissions. The data clearly show that learners are not dropping objects indiscriminately. On the contrary, they omit objects whose referents are recoverable from the ongoing discourse, that is, highly accessible referents that would normally be encoded with clitic forms. This is assumed by Silva-Corvalán (1994) in her description of such omissions among Spanish-English bilinguals (she compares them to other kinds of omissions involving dative and reflexive clitics). Similarly, Fujino and Sano (2002: 80) reach the same conclusion regarding children's null objects: 'there seem to be virtually no omission of lexical NP objects. Children's null objects are restricted to objects intended as clitics.' The reason why lexical NPs are not candidates for object drop is because of their information status: crosslinguistically, full NPs encode new referents that cannot be easily recovered from the context or those that are retrieved with great difficulty due to memory constraints (Ariel, 1991). Null objects, on the other hand, are reserved for anaphoric DOs.

\section{Relationship between judgement data and oral production}

One goal of this study was to determine if oral production tasks and grammaticality judgements yield similar information with respect to null objects in L2 Spanish. Previous studies of null objects have focused exclusively on one data source (either oral production or acceptability judgements). By looking at production and metalinguistic data in conjunction, we are able to examine the phenomenon from two different perspectives. The data presented here suggest that there is a complex relationship between learners' judgements of null objects and their omission of objects during oral production. The original correlation between these two variables was positive $(r=.37)$ and statistically significant, but additional analyses point to the influence of a mediating variable in the relationship: the production of DO clitics. Learners who display a high rate of DO clitics in oral production are less likely to omit objects in speech or accept them on a written test of grammaticality. On the contrary, learners who produce few or no DO clitics are more likely to 
accept null objects on the GJT and also omit more objects often during semi-spontaneous oral production.

The performance of the beginning-level learners on the GJT suggests that null objects are particularly difficult to detect, especially when the antecedent is found in the preceding clause, as in the target sentences. It has been suggested by Swain $(1985 ; 1995)$ that comprehension (unlike production) is a semantically driven process. Similarly, VanPatten (1996) has claimed that learners process sentences for meaning before they attend to form. In the specific case of grammaticality judgement tasks, Davies and Kaplan (1998) used a think-aloud protocol to show that intermediate learners frequently relied on a meaning-based strategy to judge sentences in their L2. Specifically, Davies and Kaplan (1998: 195) cite an example of learners rejecting a grammatical sentence because they could not fully interpret the reference of a pronominal form. If beginning-level learners rely primarily on semantic information to comprehend (and evaluate) the sentences they are presented with, it is possible that their parser 'fills in' the missing object because it is easily recoverable from the preceding clause. In other words, these learners simply may not notice the missing object, and judge the sentence as 'correct' because they understand it. This reflects the very nature of null objects in L2 Spanish: they are acceptable from a discourse-pragmatic perspective, but syntactically off-target.

More proficient learners, by definition, have a greater command of the L2 syntax. When parsing sentences with null objects they are more likely to notice the missing argument despite the fact that it is pragmatically recoverable. Recall that the advanced learners in this study were extremely accurate in rejecting the sentences with null objects. To summarize, learners' performance on the GJT could be due to differential strategy use: lower proficiency learners rely primarily on meaning (leading them to accept sentences with a null object) while more proficient learners are more in tune to syntactic violations, which explains their rejection of such sentences.

The data from the correlation analysis reported here differs from that of Leow (1966), who found a much stronger relationship between performance on a grammaticality judgement task and performance on written/oral production tasks. However, the studies are not directly comparable because of many methodological differences: the level of 
the learners, the linguistic item that was targeted and the nature of the tasks. Leow tested only one group of learners and the production tasks (both oral and written) were more focused in the sense that learners had to answer a limited number of questions using complete sentences. It is clear that more studies are needed to shed light on the complex relationship between grammaticality judgement tasks and oral production.

\section{Are null objects a grammatical or performance phenomenon?}

A grammatical account of null objects would predict that learners pass through a null object stage at some point during their interlanguage development, due to faulty parameter setting (see Hyams, 1986) or another explanation (e.g. optional spell-out as proposed by Fujino and Sano, 2002). In any case, we should expect to see a clear separation in the data, that is, a null-object stage characterized by frequent omission, followed by a stage of object suppliance. In addition, the early stage should be characterized by the systematic omission of objects with a wide variety of transitive verbs.

The data presented in this article are more consistent with a performance account for several reasons. First, the overall frequency of null objects in L2 production is so low that it seems difficult to argue for a null object 'stage'. Recall that most researchers in child language acquisition seem to set this threshold at $10 \%$, and that Spanish-speaking children display a rate of almost $50 \%$ during a certain period of time (Fujino and Sano, 2002). It seems more reasonable to view null objects in L2 Spanish as isolated events rather than a characteristic feature of a particular developmental stage. Moreover, not all of the tokens of null objects were produced by the lowest proficiency learners, as a grammatical account would predict; even some of the more advanced learners occasionally omitted obligatory objects.

The self-corrections present in the data (refer to example 20) provide additional support for a performance explanation. I interpret these examples of repair as attempts to fill the missing object slot, which suggests that learners, when monitoring their speech, rejected their initial production of null objects. This is precisely what we would expect if performance factors were influencing learners' object omissions. Moreover, the frequent omission of objects with three-argument verbs such as poner 
'to put' suggests a frequency effect according to which certain transitive verbs promote null objects, a finding that could not be easily incorporated into a grammatical account.

Additional evidence against the feasibility of a grammatical model is the frequency of null objects in certain discourse contexts and the presence of intra-subject variability. If null objects were due to a deficit in knowledge of argument structure (i.e. a learner analysing poner 'to put' as intransitive), we would expect systematic omission of objects with that particular verb. However, the data show that this is not the case; individual learners used the same verb with and without a direct object, sometimes even during the same oral task. If null objects were due to a faulty representation of the grammar (i.e. learners considering Spanish to be a $[+]$ null object language), then one might expect to find null objects across more discourse contexts. The data, however, show that null objects are generally restricted to coordinated clauses and referents that are easily recoverable from preceding discourse (i.e. the referents that would normally be encoded with clitics). Given this finding, there is need for an integrated account of null objects in SLA, one that combines performance limitations and discourse-pragmatic factors (compare Allen, 2000).

In reviewing the findings from the grammaticality judgement task, however, it could be argued that the GJT data provide some support for a grammatical account of null objects in L2 Spanish. The fact that beginning-level learners overwhelmingly accepted null objects could be an indication that they believe Spanish to be a [+ null object $]$ language. The advanced learners, on the other hand, clearly realize that Spanish does not permit definite null objects. The problem with this interpretation is that beginning level learners tended to accept all sentence types, both grammatical and ungrammatical. For example, they also accepted sentences with postverbal clitics in finite contexts (despite accepting the grammatical items with preverbal clitics). Thus, the GJT data from beginning level learners must be interpreted with extreme caution. Davies and Kaplan (1998: 199) argue that 'GJ tasks are only going to provide valid and reliable data when the subjects being tested have attained sufficient proficiency in the L2.' In similar fashion, Gass (2001) cautions that methodologies appropriate for eliciting data from native speakers may not be suitable for L2 learners. Consequently, 
it would be misguided to base a potential grammatical model of null objects in SLA on the results of the GJ task, especially from lower proficiency learners.

If a performance account is to be adopted, what kind of processing difficulty is responsible for object omission? Cleary, an L2 processing account of null objects would have to differ from that of Bloom (1990) for child language, in which the length of the utterance determines the probability of an argument being omitted. The L2 learners in this study omitted objects in the context of lengthy utterances with locative phrases. ${ }^{12}$ The data from this study suggest that the number of arguments to be expressed is more relevant than the length of the utterance. Thus, verbs that take three arguments are more likely to promote omission than two-argument verbs, as long as the conditions for recoverability are satisfied by preceding discourse.

In formulating a revised processing account, one must begin with a model of speech production (e.g. Levelt, 1989; de Bot, 1992, Kormos, 2006). A working hypothesis would be to postulate a breakdown in production induced by preverbal clitics that takes place during phonological encoding. Processing explanations maintain that elements are omitted when computation becomes too difficult (compare Bloom, 1990), and that any additional burden on working memory will promote omission. In Spanish, the linearization problem caused by preverbal clitics is bound to have an important effect on how anaphoric reference is realized. For example, producing an OV structure like lo comió ('he/she ate it') involves retrieving the appropriate lemma from the lexicon ( $\mathrm{com}$ ), adding the appropriate markers for person, tense, aspect and mood (ió), and attaching the clitic lo preverbally. The morphological complexity created by suffixes and prefixes together imposes a greater load on working memory (Daneman and Case, 1981).

In addition to the linearization problem, difficulty in retrieving a lemma is likely to have an effect on a learner's ability to make anaphoric reference. As de Bot (1992) explains, lexical retrieval problems are

\footnotetext{
${ }^{12}$ Interestingly, child learners of Spanish do this as well, as cited in Fujino and Sano (2002). The length of the utterance is not at issue here, but rather the information value of the constituent that is omitted. Greenfield and Smith (1976) were the first to propose a discourse explanation for argument omission in child language (the Principle of Informativeness), arguing that children omit information that is easily recoverable from the context. Although this notion was rejected by Hyams (1986), it has been reexamined more recently by Allen (2000).
} 
commonplace in non-balanced bilinguals because the items may have never been acquired in the first place, or simply because retrieval time surpasses what the production system will allow. Similarly, verbal inflections are notoriously difficult for English-speaking learners of Spanish, given the syncretism of tense, aspect, mood, person and number marking. MacWhinney (1996: 311-12) accurately points out that Spanish verbal morphology places 'heavy demands of working memory and phonological rehearsal'.

\section{Conclusions}

This study has presented data from oral production tasks and a metalinguistic judgement task pertaining to null objects in L2 Spanish. The results reveal that L2 learners occasionally omit definite direct objects during oral production, but only when no pragmatic infelicity results from such omission. The results from the written GJT indicate that lower proficiency learners readily accept null objects, while more proficient learners almost categorically reject such argument omissions. The results from a series of correlations computed between learners' performance on these two tasks suggests that there is some relationship between oral production and grammaticality judgements, but that a mediating variable has an effect on this correlation. It was further speculated that the results of the GJT could be a consequence of differential strategy use: while lower proficiency learners rely primarily on semantic strategies to evaluate sentences, more proficient learners are sensitive to syntactic properties and, thus, to illicit argument omission.

After examining both performance and grammatical models of argument omission, it was determined that null objects in SLA are more likely a result of performance factors. The evidence for this includes the lack of a clear null object stage, the presence of self-corrections in the oral data, the discourse distribution of null objects, and variability within participants. The details of such a performance model were not developed in this study, but it was suggested that a number of factors (e.g. verb type, lexical retrieval problems, verbal morphology) are likely to influence the occurrence of object omission. Future studies should manipulate task content to include known and novel lexical items, which could provide additional support for a performance account of null objects. 


\section{References}

Adiv, E. 1984: Language learning strategies: the relationship between L1 operating principles and language transfer in L2 development. In Andersen, R.W., editor, Second languages: a cross-linguistic perspective. Rowley, MA: Newbury House, 125-142.

Al-Kasey, T. and Pérez-Leroux, A.T. 1998: Second language acquisition of Spanish null subjects. In Flynn, S., Martohardjono, G. and O'Neil, W., editors, The generative study of second language acquisition. Mahwah, NJ: Lawrence Erlbaum.

Allen, S. 2000: A discourse-pragmatic explanation for argument structure representation in child Inuktitut. Linguistics 38, 483-521.

Andersen, R.W. 1983: Transfer to somewhere. In Gass, S. and Selinker, L., editors, Language transfer in language learning. Rowley, MA: Newbury House, 177-201.

Ariel, M. 1990: Accessing noun-phrase antecedents. London: Routledge.

- 1991: The function of accessibility in a theory of grammar. Journal of Pragmatics 16, 443-63.

Bentivoglio, P. 1992: Linguistic correlations between subjects of one-argument verbs and subjects of more-than-one argument verbs in Spoken Spanish. In Hirschbüler, P. and Koerner, K., editors, Romance languages and modern linguistic theory. Philadelphia, PA: Benjamins, 11-24.

Birdsong, D. 1989: Metalinguistic performance and interlanguage competence. New York: Springer.

Bloom, P. 1990: Subjectless sentences in child language. Linguistic Inquiry 21, 491-504.

Bruhn de Garavito, J. and Guijarro-Fuentes, P. 2002: L2 acquisition of indefinite object drop. In Costa, J. and Freitas, M.J., editors, GALA 2001 Proceedings. Lisbon: Associação Portuguesa de Linguística, 60-67.

Camacho, J., Paredes, L. and Sánchez, L. 1997: Null objects in Andean Bilingual Spanish. In Hughes, E., Hughes, M. and Greenhill, A., editors, Proceedings of the Twenty-First Annual Boston University Conference on Language Development. Somerville, MA: Cascadilla Press, 56-66.

Campos, H. 1986: Indefinite object drop. Linguistic Inquiry 17, 354-59.

Chaudron, C. 1983: Research on metalinguistic judgments: a review of theory, method, and results. Language Learning 33, 343-377.

Chaudron, C. 2003: Data collection in SLA research. In Doughty, C. and Long, M., editors, The handbook of second language acquisition. Oxford: Blackwell, 762-828.

Choi, J. 2000: Direct object drop: the genetic cause of a syntactic feature in Paraguayan Spanish. Hispania 83, 531-43.

Christie, K. and Lantolf, J. 1992: The ontological status of learner grammaticality judgments in UG approaches to language acquisition. Rassegna Italiana di Linguistica Applicata 3, 31-57. 
Clements, J.C. 1994: Notes on topicalization and object drop in Spanish. In Mazzola, M., editor, Issues and theory in Romance linguistics: selected papers from the linguistic symposium on Romance languages XXIII. Washington, DC: Georgetown University Press, 219-37. 2006: Null direct objects in Spanish. In Clements, J.C. and Yoon, J., editors, Functional approaches to Spanish syntax. New York: Palgrave, 134-50.

Colantoni, L. 2002: Clitic doubling, null objects and clitic climbing in the Spanish of Corrientes. In Gutiérrez-Rexach, J., editor, From words to discourse: trends in Spanish semantics and pragmatics. Oxford: Elsevier, 321-36.

Company, C. 2001: Multiple dative-marking grammaticalization: Spanish as a special kind of primary object language. Studies in Language 25, 1-47.

Daneman, M. and Case, R. 1981: Syntactic form, semantic complexity, and short-term memory: influences on children's acquisition of new linguistic structures. Developmental Psychology 17, 367-78.

Davies, W.D. and Kaplan, T.I. 1998: Native speaker vs. L2 learner grammaticality judgements. Applied Linguistics 19, 183-203.

de Bot, K. 1992: A bilingual production model: Levelt's 'Speaking' model adapted. Applied Linguistics 13, 1-24.

dePaola, T. 1978: Pancakes for breakfast. San Diego, CA: Voyager Books/ Harcourt Brace.

Ellis, R. 1991: Grammaticality judgments and second language acquisition. Studies in Second Language Acquisition 13, 161-86.

Ellis, R. and Rathbone, M. 1987: The acquisition of German in a classroom context. Mimeograph. London: Ealing College of Higher Education.

Escobar, A.M. 1990: Los bilingües y el castellano en el Perú. Lima, Perú: Instituto de Estudios Peruanos.

Fujino, H. and Sano, T. 2000: Some notes on the null object phenomenon in child Spanish. In Howell, S.C., Fish, S.A. and Keith-Lucas, T., editors, Proceedings of the Boston University Conference on Language Development 24, Somerville, MA: Cascadilla Press, 308-18.

2002: Aspects of the null object phenomenon in child Spanish. In PérezLeroux, A.T. and Liceras, J.M., editors, The acquisition of Spanish morphosyntax. Dordrecht: Kluwer Academic, 67-88.

Gass, S. 1994: The reliability of second-language grammaticality judgments. In Tarone, E., Gass, S. and Cohen, A., editors, Research methodology in second language acquisition. Hillsdale, NJ: Lawrence Erlbaum, 303-22. 2001: Sentence matching: a reexamination. Second Language Research 17, 421-41.

Gerken, L. 1991: The metrical basis for children's subjectless sentences. Journal of Memory and Language 30, 431-51.

Gillian, B., Malmkjaer, K. and Williams, J., editors, 1996: Performance and competence in second language acquisition. Cambridge: Cambridge University Press. 
Givón, T. 1984: Syntax: a functional-typological introduction, volume 1. Amsterdam: John Benjamins.

Greenfield, P. and Smith, J. 1976: The structure of communication in early language development. New York: Academic Press.

Guasti, M. 1994: Verb syntax in Italian child grammar: finite and non-finite verbs. Language Acquisition 3, 1-40.

Gundel, J., Stenson, N. and Tarone, E. 1984: Acquiring pronouns in a second language: evidence for hypothesis testing. Studies in Second Language Acquisition 6, 215-25.

Gundel, J. and Tarone, E. 1992: Language transfer and the acquisition of pronouns. In Gass, S. and Selinker, L., editors, Language transfer in language learning, revised edition. Amsterdam: John Benjamins, 87-100.

Hedgcock, J. 1991: Foreign language retention and attrition: a study of maintenance patterns among adult learners of Spanish. Unpublished $\mathrm{PhD}$ dissertation, University of Southern California, Los Angeles, CA.

Huang, C.-T.J. 1984: On the distribution and reference of empty pronouns. Linguistic Inquiry 15, 531-74.

Hyams, N. 1983: Acquisition of parameterized grammar. Unpublished dissertation, The City University of New York, New York, NY.

1986: Language acquisition and the theory of parameters. Dordrecht: Reidel.

1994: Null subjects in child language and the implications of crosslinguistic variation. In Lust, B., Hermon, G. and Kornfilt, J., editors, Syntactic theory and first language acquisition: cross-linguistic perspectives; volume 2: Binding, dependencies, and learnability, Hillsdale, NJ: Lawrence Erlbaum.

Hyams, N. and Wexler, K. 1993: On the grammatical basis of null subjects in child language. Linguistic Inquiry 24, 421-59.

Isabelli, C. 2004: The acquisition of the null subject parameter properties in SLA: some effects of positive evidence in a naturalistic learning context. Hispania 87, 150-62.

Kany, C. 1945: American-Spanish syntax. Chicago, IL: University of Chicago Press.

Klee, C. 1989: The acquisition of clitic pronouns in the Spanish interlanguage of Peruvian Quechua speakers. Hispania 72, 402-08.

Kormos, J. 2006: Speech production and second language acquisition. Mahwah, NJ: Lawrence Erlbaum.

Landa, M.A. 1995: Conditions on null objects in Basque Spanish and their relation to leísmo and clitic doubling. Unpublished $\mathrm{PhD}$ dissertation, University of Southern California, Los Angeles, CA.

Lardiere, D. 2000: Mapping features to forms in second language acquisition. In Archibald, J., editor, Second language acquisition and linguistic theory, Oxford: Blackwell, 102-29. 
Lee, J.F. 2003: Cognitive and linguistic perspectives on the acquisition of object pronouns in Spanish as a second language. In Lafford, B. and Salaberry, R., editors, Spanish second language acquisition: the state of the science. Washington, DC: Georgetown University Press, 98-129.

Leow, R. 1996: Grammaticality judgment tasks and second-language development. Georgetown University Round Table on Languages and Linguistics, 126-39.

Levelt, W. 1989: Speaking: from intention to articulation. Cambridge, MA: MIT Press.

Liceras, J. 1989: On some properties of the pro-drop parameter: looking for missing subjects in non-native Spanish. In Gass, S. and Schachter, J., editors, Linguistic perspectives on second language acquisition. Dordrecht: Foris.

Lipski, J. 1994: Latin American Spanish. London: Longman.

MacWhinney, B. 1996: Language specific prediction in foreign language learning. Language Testing 12, 292-320.

Masullo, P.J. 2003: Clitic-less definite object drop in River Plate Spanish. Unpublished paper presented at LSRL XXXIII, Indiana University.

Montrul, S. 2004: The acquisition of Spanish: morphosyntactic development in monolingual and bilingual first language acquisition and in adult second language acquisition. Amsterdam: John Benjamins.

Moore, J. 1996: Reduced constructions in Spanish. New York: Garland Publishers.

Müller, N., Crysmann, B. and Kaiser, G.A. 1996: Interactions between the acquisition of French object drop and the acquisition of the C-system. Language Acquisition 5, 35-63.

Müller, N. and Hulk, A. 2001: Crosslinguistic influence in bilingual language acquisition: Italian and French as recipient languages. Bilingualism: Language and Cognition 4, 1-21.

Paredes, L. 1996: The Spanish continuum in Peruvian bilingual speakers: a study of verbal clitics. Unpublished PhD dissertation, University of Southern California, Los Angeles, CA.

Pérez-Leroux, A.T. and Glass, W.R. 1999: Null anaphora in Spanish SLA. Second Language Research 15, 220-49.

Phinney, M. 1987: The pro-drop parameter in second language acquisition. In Roeper, T. and Williams, E., editors, Parameter setting. Dordrecht: Kluwer.

Polio, C. 1995: Acquiring nothing? The use of zero pronouns by nonnative speakers of Chinese and the implications for the acquisition of nominal reference. Studies in Second Language Acquisition 17, 353-77.

Prévost, P. and White, L. 2000: Missing surface inflection or impairment in second language acquisition? Evidence from tense and agreement. Second Language Research 16, 103-33.

Radford, A. 1990: Syntactic theory and the acquisition of English syntax: the nature of early grammars of English. Oxford: Blackwell. 
Reig, A. and Schwenter, S. 2006: Null Objects and Neuter lo: a cross-dialectal variationist analysis. Unpublished paper presented at Third International Workshop on Spanish Sociolinguistics, Philadelphia, PA.

Sánchez, L. 1999: Null objects in contact varieties of Spanish. In Authier, J.-M., Reed, L. and Bullock, B., editors, Formal perspectives on Romance linguistics. Amsterdam: John Benjamins, 227-42.

2002: The acquisition of interpretable phi-features in L1 and L2/bilingual speakers in language contact situations. In Liceras, J. and PerezLeroux, A.T., editors, The acquisition of Spanish morphosyntax. Amsterdam: Kluwer Academic, 87-112.

Sánchez, L. and Al-Kasey, T. 1999: L2 acquisition of Spanish direct objects. Spanish Applied Linguistics 3,1-32.

Sanz, C. 1997: Experimental tasks in SLA research: amount of production, modality, memory, and production processes. In Glass, W.R. and PérezLeroux, A.T., editors, Contemporary perspectives on the acquisition of Spanish; volume 2: Production, processing, and comprehension, Somerville, MA: Cascadilla, 41-55.

Schwenter, S. 2006: Null objects across South America. In Face, T. and Klee, C., editors, Selected proceedings of the 8th Hispanic Linguistics Symposium. Somerville, MA: Cascadilla Press, 23-36.

Silva-Corvalán, C. 1994: Language contact and change: Spanish in Los Angeles. New York: Oxford University Press.

Sorace, A. 1996: The use of acceptability judgments in second language acquisition research. In Bhatia, V.T. and Ritchie, W., editors, Handbook of second language acquisition. New York: Academic Press, 375-409.

Suñer, M. and Yépez, M. 1988: Null definite objects in Quiteño. Linguistic Inquiry 18, 511-51.

Swain, M. 1985: Communicative competence: some roles of comprehensible input and comprehensive output in its development. In Gass, S. and Madden, C., editors, Input in second language acquisition. Rowley, MA: Newbury House, 235-53.

1995: Three functions of output in second language learning. In Cook, G. and Seidlehofer, B., editors, Principle and practice in applied linguistics: studies in honor of H.G. Widdowson. Oxford: Oxford University Press, 125-44.

Torres, J. 2003: The acquisition of clitics in L2 Spanish: a discourse/functional perspective of lexical NPs vs. clitics. In Montrul, S. and Ordóñez, F., editors, Linguistic theory and language development in Hispanic languages. Somerville, MA: Cascadilla Press, 447-67.

Uziel-Karl, S. and Berman, R.A. 2000: Where's ellipsis? Whether and why there are missing arguments in Hebrew child language. Linguistics 38, $457-82$.

Valian, V. 1990: Null subjects: a problem for parameter-setting models of language acquisition. Cognition 35, 105-22. 
- 1991: Syntactic subjects in the early speech of American and Italian children. Cognition 40, 21-81.

VanPatten, B. 1987: Classroom and naturalistic language acquisition: a comparison of two case studies in the acquisition of Spanish clitic pronouns. In Morgan, T., Lee, J. and VanPatten, B., editors, Language and language use: Studies in Spanish. Landham, MD: University Press of America, 241-262.

- 1996: Input processing and grammar instruction: theory and research. Norwood: ABLEX.

VanPatten, B. and Sanz, C. 1995: From input to output: processing instruction and communicative tasks. In Eckman, F., Highland, D., Lee, P., Mileham, J. and Weber, R., editors, Second language acquisition theory and pedagogy. Hillsdale, NJ: Lawrence Erlbaum, 169-86.

Véronique, D. 1989: Reference and discourse structure in the learning of French by adult Moroccans. In Dechert, H.W., editor, Current trends in European second language acquisition research, Clevedon: Multilingual Matters, 171-201.

Wang, Q., Lilo-Martin, D., Best, C. and Levitt, A. 1992: Null subjects vs. null objects: some evidence from the acquisition of Chinese and English. Language Acquisition 2, 221-54.

White, L. 1996: Clitics in L2 French. In Clahsen, H., editor, Generative perspectives on language acquisition: empirical findings, theoretical considerations and crosslinguistic comparisons. Amsterdam: John Benjamins, 335-68.

2003: Second language acquisition and Universal Grammar. Cambridge: Cambridge University Press.

Williams, J. 1988: Zero anaphora in second language acquisition: a comparison among three varieties of English. Studies in Second Language Acquisition 10, 339-70.

1989: Pronoun Copies, pronominal anaphora and zero anaphora in second language production. In Gass, S., Madden, C., Preston, D. and Selinker, L., editors, Variation in second language acquisition; volume I: Discourse and pragmatics. Clevedon: Multilingual Matters, 153-89.

Yuan, B. 1997: Asymmetry of null subjects and null objects in Chinese speakers' L2 English. Studies in Second Language Acquisition 19, 467-97.

Zobl, H. 1994: Prior linguistic knowledge and the conservation of the learning procedure: grammaticality judgements of unilingual and multilingual learners. In Gass, S. and Selinker, L., editors, Language transfer in language learning. Amsterdam: John Benjamins, 176-96.

Zyzik, E. 2004: Encoding meaning with polyfunctional forms: the acquisition of clitics in L2 Spanish. Unpublished PhD dissertation, University of California, Davis, CA.

- 2006: Learners' overgeneralization of dative clitics to accusative contexts: evidence for prototype effects in SLA. In Klee, C. and Face, T., editors, Selected proceedings of the 7th Conference on the Acquisition of Spanish and Portuguese as First and Second Languages. Somerville, MA: Cascadilla Press, 122-34. 
Appendix 1 Storybook narration task

The following glossary provides the vocabulary needed to complete the task. Listen to the words as they are pronounced. You will have three minutes to study the words.

$\begin{array}{llll}\text { el delantal } & \text { 'apron' } & \text { el establo } & \text { 'barn' } \\ \text { la receta } & \text { 'recipe' } & \text { la mantequilla } & \text { 'butter' } \\ \text { el estante } & \text { 'shelf' } & \text { el jarabe } & \text { 'syrup' } \\ \text { los ingredientes } & \text { 'ingredients' } & \text { el olor } & \text { 'a smell/scent' } \\ \text { la harina } & \text { 'flour' } & \text { sacar } & \text { 'to take out' } \\ \text { el recipiente } & \text { 'bowl' } & \text { poner } & \text { 'to put' } \\ \text { el gallinero } & \text { 'henhouse' } & \text { echar } & \text { 'to pour / to put' } \\ \text { las gallinas } & \text { 'chickens' } & \text { ordeñar la vaca } & \text { 'to milk the cow' } \\ \text { la canasta } & \text { 'basket' } & \text { revolver } & \text { 'to stir' }\end{array}$

You will be given a children's book that tells a story entirely through pictures. Take a few minutes to look at the pictures so that you can understand what happens. Your task consists of telling the story in Spanish, including as much detail as possible. Try not to leave out any actions, because another student will have to write report based on your narration. After you finish telling the story, the researcher will ask you some questions about the plot and characters. If you have any questions, ask them now.

Appendix 2 Structured interview task

1) ¿Qué tiempo hace afuera?

'What is the weather like outside?'

2) ¿Qué está haciendo la mujer en este dibujo?

'What is the woman doing in this picture?'

3) Y aquí, ¿qué hace la mujer con el libro?

'And here, what is the woman doing with the book?

4) Y luego va a la cocina, y en este dibujo ¿qué hace con la harina?

'And next she goes to the kitchen, and in this picture, what is she doing with the flour?'

5) Ella va al gallinero y ¿qué hace con los huevos?

'She goes to the henhouse and what does she do with the eggs?'

6) Entonces ella va al establo, y ¿qué hace el gato?

'Then she goes to the barn, and what does the cat do?'

7) ¿Cómo se siente la mujer mientras prepara la mantequilla?

'How does the woman feel while she makes the butter?'

8) ¿Cómo consigue el jarabe?

'How does she get the syrup?'

9) Cuando la mujer entra en la casa, ¿dónde está la leche?

'When she enters her house, where is the milk?'

10) ¿Qué hace el vecino cuando ve a la mujer en la puerta?

'What does the neighbor do when he sees the woman at the door?' 


\section{Null objects in SLA: Grammatical vs. performance models}

\section{Appendix 3 Video narration task 1}

The following glossary provides the vocabulary needed to complete the task. Listen to the words as they are pronounced. You will have three minutes to study the words.

$\begin{array}{llll}\text { abrazar } & \text { 'to hug' } & \text { el abrigo } & \text { 'coat' } \\ \text { quitar } & \text { 'to take off' } & \text { el sillón } & \text { 'armchair' } \\ \text { tirar } & \text { 'to throw' } & \text { el armario } & \text { 'closet/cabinet' } \\ \text { poner } & \text { 'to put' } & \text { la cena } & \text { 'dinner' } \\ \text { servir } & \text { 'to serve' } & \text { el café } & \text { 'coffee' } \\ \text { traer } & \text { 'to bring', } & \text { la manta } & \text { 'blanket' } \\ \text { tapar } & \text { 'to cover' } & \text { el sofa } & \text { 'couch/sofa' }\end{array}$

What you are about to see is a video clip that represents a short story. The main characters are Pablo and Camila. The story begins when Camila returns home after a long day at work. Your task consists of watching the video clip and then telling the story. Try not to forget any action, because another student will write a report based on your description. The video clip will be shown twice. During the first viewing, pay close attention to what is happening. Then during the second viewing, narrate what happens. If you have any questions, ask them now.

\section{Appendix 4 Video narration task 2}

The following glossary provides the vocabulary needed to complete the task. Listen to the words as they are pronounced. You will have three minutes to study the words.

$\begin{array}{llll}\text { quitar } & \text { 'to take off' } & \text { limpiar } & \text { 'to clean' } \\ \text { poner } & \text { 'to put' } & \text { peinar } & \text { 'to comb' } \\ \text { sacar } & \text { 'to take out' } & \text { el collar } & \text { '(dog) collar' } \\ \text { abrir el grifo } & \text { 'to turn on the water' } & \text { la bañera } & \text { 'bathtub' } \\ \text { mojar } & \text { 'to wet, to make wet' } & \text { las toallas } & \text { 'towels' } \\ \text { bañar } & \text { 'to bathe' } & \text { el champú } & \text { 'shampoo' } \\ \text { secar } & \text { 'to dry' } & \text { la secadora } & \text { 'dryer' } \\ \text { enjuagar } & \text { 'to rinse' } & \text { la galletita } & \text { 'cookie, treat' }\end{array}$

What you are about to see is a video clip that represents a short story. The main character is a girl named Carmen, and she is bathing her dog, Tico. Your task consists of watching the video clip and then telling the story. Try not to forget any action, because another student will write a report based on your description. The video clip will be shown twice. During the first viewing, pay close attention to what is happening. Then during the second viewing, narrate what happens. If you have any questions, ask them now. 